\title{
PLANKTON STUDIES IN A MANGROVE ENVIRONMENT. IV. SIZE FRACTIONATION OF THE PHYTOPLANKTON
}

(Received in 16/1/1967)

\author{
C. Teixeira, J. Tundisi \\ Instituto Oceanográfico da Universidade de São Paulo \\ $\&$ \\ J. SANTORo * \\ Instituto Nacional de Pesca, Guayaquil
}

\begin{abstract}
SYNOPSIS
The seasonal variation of the different fractions of photosynthesizing phytoplankton, measured by $\mathrm{C}-14$ uptake, was studied in a mangrove swamp region, at $25^{\circ}$ south latitude. The data showed that the fraction with size range from $5 \mu$ to $65 \mu$ was responsible for an average of $61.80 \%$ of $\mathrm{C}-14$ uptake of the phytoplankton, during one year, samples having been taken every other month, and showed little seasonal variation when compared with the fraction larger than $65 \mu$.
\end{abstract}

The results presented here, confirmed general conclusions of other authors, and provided a back-ground for future investigation in the area.

\section{INTRODUCTION}

The fractionation of the phytoplankton in constituents of various size range, has received much attention in the last few years.

However little evidence has been accumulated to understand the role played by different fractions in tropical waters.

The work of Steemann-Nielsen (1938), Riley (1941), Harvey (1950), Wood and Davis (1956), Steemann-Nielsen and Jensen (1957), has shown that a great majority of the phytoplankton in most part of the oceans pass through the fine nets.

Relatively larger percentages of net-phytoplankton were found in eutrophic waters (DIGBY, 1953), as compared to oligotrophic waters (RILEY, 1957; Steemann-Nielsen and Jensen, 1957; Hulburt, Ryther and Guillard, 1960; Teixeira, 1963), where it was demonstrated that net-phytoplankton represents a small percentage of the total phytoplankton, while the nannophytoplankton, is relatively more important.

\footnotetext{
- FAO fellow at the Instituto Oceanográfico in 1965.
} Publ. n.o 242 do Inst. Ocean. da USP.
The investigation reported here, was carried out at every other month, during six months, 1965, at a single station, in a mangrove swamp region of the estuarine type, at $25^{\circ}$ south latitude (enclosed sketch). It reports on the seasonal variation of the relative rate of C-14 uptake by different size groups of the phytoplankton.

\section{METHODS}

Light penetration was measured with a subma. rine hydrophotometer, equipped with blue-green glass filters.

Water samples were collected at surface, $(100 \%$ light penetration) and at $25 \%$ light penetration with Nansen bottles.

Chlorinity was measured by titration with silver nitrate, and dissolved oxygen, was determined by the Winkler method, unmodified (Tномpson AND Robinson, 1939).

Samples for fractionation of the phytoplankton were collected with insulated Petersen-Nansen bottles, at the two depths given above. 


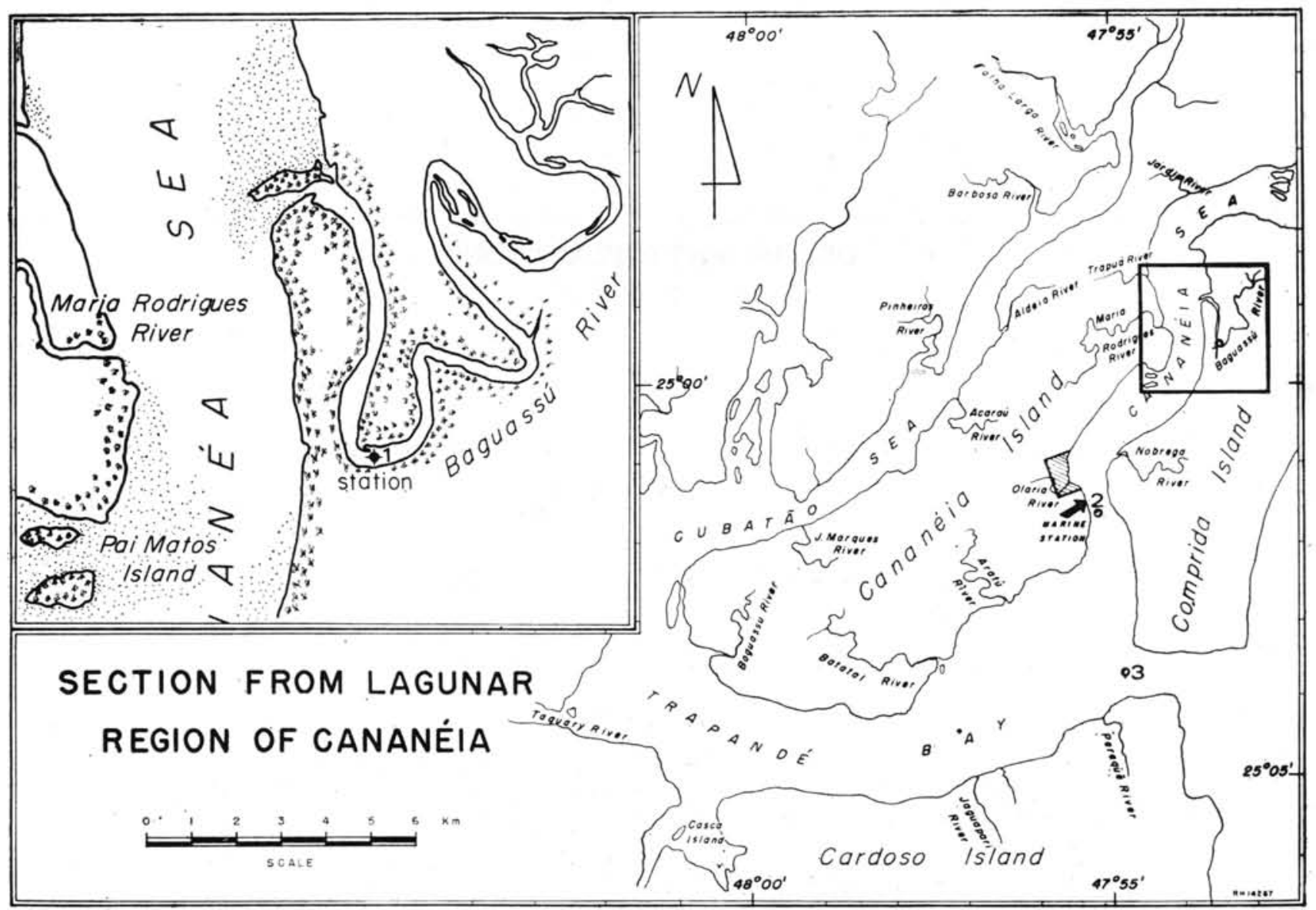

Sketch of the lagunar region at Cananéia, showing in detail, station position.

TABLE I - Nannophytoplankton and net-phytoplankton from surface and depth, in percent, and hydrographical data

\begin{tabular}{|c|c|c|c|c|c|c|c|c|c|c|c|c|c|c|c|}
\hline \multirow{2}{*}{ Month } & \multicolumn{2}{|c|}{$\begin{array}{l}\text { Nannophyto- } \\
\text { plankton }(\%)\end{array}$} & \multicolumn{2}{|c|}{$\begin{array}{l}\text { Net-phyto- } \\
\text { plankton (\%) }\end{array}$} & \multicolumn{2}{|c|}{$\begin{array}{c}\text { Temperature } \\
{ }^{\circ} \mathrm{C}\end{array}$} & \multicolumn{2}{|c|}{$\begin{array}{l}\text { Salinity } \\
\% / 00\end{array}$} & \multicolumn{2}{|c|}{$\begin{array}{l}\text { Oxygen } \\
\text { cc/L }\end{array}$} & \multicolumn{2}{|c|}{$\mathrm{pH}$} & \multirow{2}{*}{$\begin{array}{l}\text { Precipi- } \\
\text { tation } \\
\text { high in } \\
\mathrm{mm} / 5 \mathrm{~d} .\end{array}$} & \multirow{2}{*}{$\begin{array}{c}\text { Transpa- } \\
\text { rency } \\
\mathrm{K}=1.7 / \mathrm{d}\end{array}$} & \multirow{2}{*}{ Tide } \\
\hline & 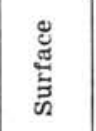 & 追 & 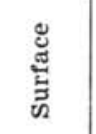 & 点 & 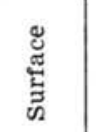 & 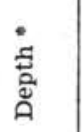 & 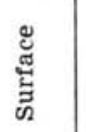 & 동 & 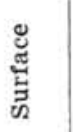 & 趍 & 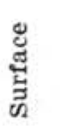 & 岳 & & & \\
\hline February & 95.28 & 84.41 & 4.72 & 15.59 & 28.80 & 27.90 & 4.78 & 4.80 & - & - & 6.0 & 6.0 & 9.1 & 4.20 & Low \\
\hline April & 95.83 & 90.56 & 4.17 & 9.44 & 24.80 & 24.50 & 15.00 & 14.65 & 2.91 & 3.00 & 6.0 & 6.0 & 9.0 & 2.70 & Low \\
\hline June & 95.75 & 90.64 & 4.25 & 9.36 & 21.10 & 21.10 & 13.24 & 14.31 & 3.32 & 3.48 & 6.5 & 6.5 & 11.7 & 2.10 & Low \\
\hline August & 82.32 & 64.32 & 17.68 & 35.68 & 22.10 & 22.10 & 19.92 & 19.84 & 4.23 & 4.18 & 6.5 & 6.5 & 0.4 & 1.30 & High \\
\hline October & 94.34 & 80.00 & 5.66 & 20.00 & 23.42 & 23.38 & 22.61 & 23.22 & 4.37 & 4.40 & 6.5 & 6.5 & 12.7 & 1.40 & Low \\
\hline December & 87.93 & 71.37 & 12.07 & 28.63 & 25.75 & 26.15 & 8.53 & 8.95 & 3.78 & 3.80 & 6.0 & 6.0 & 18.2 & 1.10 & High \\
\hline
\end{tabular}

$*-25 \%$ light penetration 
TABLE Ii - The fractionation of nannophytoplankton in two different size range and net-phytoplankton - in percent

\begin{tabular}{|c|c|c|c|c|c|c|}
\hline \multirow{3}{*}{ Month } & \multicolumn{4}{|c|}{ Nannophytoplankton } & \multicolumn{2}{|c|}{ Net-phytoplankton } \\
\hline & \multicolumn{2}{|c|}{$0.45-5.00_{\mu}$} & \multicolumn{2}{|c|}{$5.00-65.00 \mu$} & \multicolumn{2}{|c|}{$65.00_{\mu}$} \\
\hline & Surface & Depth * & Surface & Depth * & Surface & Depth * \\
\hline February & 24.59 & 27.90 & 70.69 & 56.51 & 4.72 & 15.59 \\
\hline April & 13.33 & 22.64 & 82.50 & 67.92 & 4.17 & 9.44 \\
\hline June & 32.95 & 36.16 & 62.80 & 54.48 & 4.25 & 9.36 \\
\hline August & 27.93 & 32.28 & 54.39 & 32.04 & 17.68 & 35.68 \\
\hline October & 5.13 & 25.00 & 89.21 & 55.00 & 5.66 & 20.00 \\
\hline \multirow[t]{2}{*}{ December } & 8.33 & 34.48 & 79.60 & 36.89 & 12.07 & 28.62 \\
\hline & \multicolumn{2}{|c|}{ A } & \multicolumn{2}{|c|}{ B } & \multicolumn{2}{|c|}{ C } \\
\hline
\end{tabular}

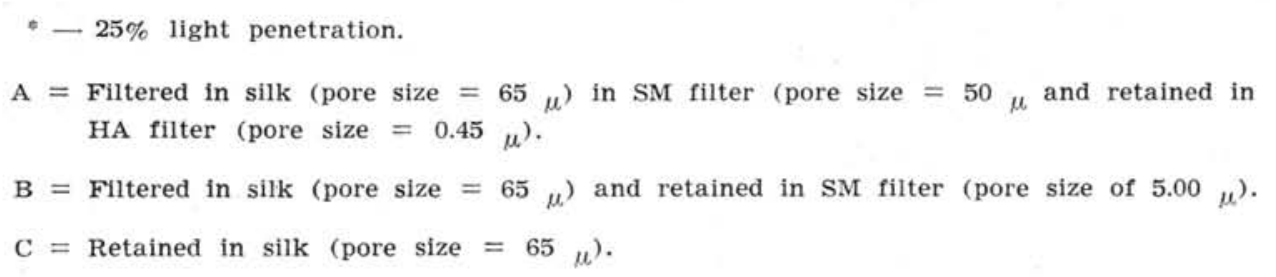

To estimate the size range of the photosynthesizing phytoplankton, the following technique was adopted: in each experiment, a surface water sample, and a sample from $25 \%$ light penetration, were inoculated with approximately $4 \mu \mathrm{C}$ of radioactive bicarbonate solution, and placed for incubation in situ during 4 hours. Incubation period was always at the same hours of the day. After incubation, the samples were passed through a series of filters in the following order: a disk of bolting silk with $65 \mu$ mesh size; a SM filter with $5 \mu$ pore size; a HA filter with $0,45 \mu$ pore size.

The pressure used during filtration of the samples was $1,5 \mathrm{Kg} / \mathrm{cm}^{2}$.

The phytoplankton, was thus divided in three fractions: larger than $65 \mu$; smaller than $65 \mu$ but larger than $5 \mu$; and smaller than $5 \mu$ and larger than $0,45 \mu$.

\section{RESULTS AND DISCUSSION}

Table I, shows the seasonal variation of th relative rates of C-14 uptake the nannophytoplankton, and the net-phytoplankton. Table II, shows the seasonal variation for the nannophytoplankton fraction of $0,45-5 \mu$ and 5 to $65 \mu$.

Values for surface and depth (i.e. 25\% light penetration) ranged from $95.83 \%$ (April) to $64.32 \%$ (August) for the fraction smaller than $65 \mu$.
Values for the net-phytoplankton, attained the greatest percentage in August, at $25 \%$ light penetration $(35.68 \%)$.

The environmental data collected showed for the amount of rainfall a minimum in August, and this coincided with a maximum for the net-phytoplankton, suggesting some influence of the coastal waters in the inshore waters.

YentsCh AND RYThER (1959) called attention to the fact, that in an estuary, the percentage of the nannophytoplankton, can be high, due to the prevalence of the smaller forms. In these estuarine areas, the bulk of the organic production, might be due to the activity of the autotrophic flagellates and small diatoms. The present investigation has showed that in the area studied, smaller forms predominate the bulk of the photosynthesizing phytoplankton, appears to be in the size range of $5 \mu$ to $65 \mu$.

The reduced seasonal variation observed in nannophytoplankton contrasted with the marked seasonal trend of the net-phytoplankton, a fact that confirms Yentsch and Ryther's investigations in Vineyard Sound.

Ballantine (1953), and Cushing (1955) emphasized the fact that little contribution can be expected from the microflagellates to the total phytoplankton biomass. However, ANDERson (1965) suggests, based on his results, that microflagellates at most times may be much more important than it was previously thought. 
It remains to be determined which is the contribution of the microflagellates to the nannophytoplankton in the area under investigation.

The causes which affect the relative percentage of C-14 uptake of the different fractions and their variation throughout the year, are unknown. Factors such as salinity, amount of rainfall, available nutrients and seasonal variation of the selective grazing of herbivores, might be of importance.

\section{ACKNOWLEDGEMENTS}

The authors wish to express their thanks to the Fundação de Amparo à Pesquisa do Estado de São Paulo, and to the Conselho Nacional de Pesquisas (Rio de Janeiro, GB) for partial support of this investigation.

\section{R ES U MO}

Os autores levaram a efeito uma série de experimentos para verificar a importância relativa de três fraçōes, obtidas artificialmente do fitoplâncton natural, nas seguintes ordens de tamanho: maiores de $65 \mu$; menores do que $65 \mu$ e maiores de $5 \mu$; e menores de $5 \mu$ e maiores de $0,45 \mu$. Para a determinação da importância seletiva das várias frações, foi usado o método do Carbôno-14.

As amostras foram coletadas durante um ano, em 6 meses alternados, no interior de um dos "marigot" da região lagunar de Cananéia (vêr mapa).

Dos resultados experimentais, pudemos verificar que há uma grande predominância dos fitoplanctontes compreendidos na fração de $5 \mu$ a $65 \mu$.

Enquanto o "net-fitoplâncton" mostrou variação sazonal, a mesma não foi verificada com relação ao nanofitoplâncton.

\section{R E F E R E N C E S}

ANDERSON, G. C.

1965. Fractionation of phytoplankton communities off the Washington and Oregon coast. Limnol. Oceanogr., vol. 10, n. ${ }^{\circ}$ 3, p. $477-479$.

Ballantine, D

1953. Comparison of the different methods of estimating nannoplankton. J. mar. biol. Ass. U. K., vol. 32, p. 129-147.
CUSHING, D. H.

1955.

Production and a pelagic fishery. Fishery Invest., Lond. ser. 2 , v. 8, n. $^{\circ} 7$.

DigBy, P. S. B.

1953. Plankton production in Scoreby Sound, East Greeland. J. Anim. Ecol., vol. 22 , p. $289-322$.

HaRVEY, H. W.

1950. On the production of living matter in the sea off Plymouth. J. mar. biol. Ass. U. K., vol. 29, n. ${ }^{\circ}$ 1, p. 97-137.

Hulburt, E. M., Ryther, J. H. \& Guillard, R. R. L. 1960. The phytoplankton of the Sargasso Sea off Bermuda. J. Cons. perm. int. Explor. Mer, vol. 25, n. ${ }^{\circ}$ 2, p. 115-128.

RILEY, G. A.

1941. Plankton studies. III. Long Island Sound. Bull. Bingham Oceanogr. Coll., vol. $7, \mathrm{n}^{\circ} 3$, p. 1-93.

1957. Phytoplankton of the north central Sargasso Sea. Limnol. Oceanogr., vol. 2, n. ${ }^{\circ} 3$, p. $252-270$.

SteemanN-Nielsen, E.

1938. Über die Anwenndung von Netzfängen bei quantitativen Phytoplankton der Suchungen. J. Cons. perm. int. Expl. Mer, vol. 13, n. $^{\circ} 2$, p. $197-205$.

Steemann-Nielsen, E. \& Jensen, E. A.

1957. Primary oceanic production. The autotrophic production of organic matter in the oceans. Galathea Rep., vol. 1, p. $49-136$.

TeIXeira, C.

1963. Relative rates of photosynthesis and standing stock of the net-phytoplankton. Bolm Inst. oceanogr. S Paulo, vol. 13, n. $^{\circ} 2$, p. $53-60$.

Thompson G. T. \& RoBINSoN, J. R.

1939. Notes on the determination of dissolved oxygen in sea water. J. mar. Res., vol. 2 , n. ${ }^{\circ} 1$, p. $1-18$

- Wood, E. F. \& Davis, P. S.

1956. Importance of smaller phytoplankton elements. Nature, Lond., v. 177, n. $^{\circ}$ 4505 , p. 438 .

Yentsch, C. S. \& RytheR, J. H.

1959. Relative significance of the net phytoplankton and nannoplankton in the waters of Vineyard Sound. J. Cons. perm. int. Expl. Mer, vol. 14, n. ${ }^{\circ}$, p. $231-238$. 